\title{
Social and Economic Aspects of Sustainable Development of Livestock Production and Meat Consumption in the Czech Republic
}

\author{
Karel Šrédl ${ }^{1} \oplus$, Marie Prášilová ${ }^{2}$, Lucie Severová ${ }^{1}$, Roman Svoboda ${ }^{1, * \mathbb{C}}$ and Michal Štěbeták ${ }^{2} \mathbb{D}$ \\ 1 Department of Economic Theories, Faculty of Economics and Management, Czech University of Life Sciences \\ Prague, Kamýcká 129, 16500 Prague 6, Czech Republic; sredl@pef.czu.cz (K.Š.); severova@pef.czu.cz (L.S.) \\ 2 Department of Statistics, Faculty of Economics and Management, Czech University of Life Sciences Prague, \\ Kamýcká 129, 16500 Prague 6, Czech Republic; prasilova@pef.czu.cz (M.P.); stebetak@pef.czu.cz (M.Š.) \\ * Correspondence: svobodar@pef.czu.cz; Tel.: +420-224-382-156
}

Citation: Šrédl, K.; Prášilová, M.;

Severová, L.; Svoboda, R.; Štěbeták,

M. Social and Economic Aspects of

Sustainable Development of

Livestock Production and Meat

Consumption in the Czech Republic.

Agriculture 2021, 11, 102. https://

doi.org/10.3390/agriculture11020102

Academic Editor: Piotr Prus

Received: 22 December 2020

Accepted: 23 January 2021

Published: 26 January 2021

Publisher's Note: MDPI stays neutral with regard to jurisdictional claims in published maps and institutional affiliations.

Copyright: (c) 2021 by the authors. Licensee MDPI, Basel, Switzerland. This article is an open access article distributed under the terms and conditions of the Creative Commons Attribution (CC BY) license (https:// creativecommons.org/licenses/by/ $4.0 /)$.

\begin{abstract}
The aim of this article was to express social and economic aspects of the sustainable livestock production in relation to meat consumption in the Czech Republic and to predict the possibilities of further development of livestock production in the conditions of Czech agriculture. With the accession of Czechia to the EU (2004), the structure of Czech agriculture changed to the detriment of livestock production. The decisive sectors of livestock production are pig breeding, cattle breeding and poultry farming. This article (contribution) analyzes trends in the development of production in the basic categories of livestock, and it evaluates the degree of self-sufficiency of the economy in the given sector of agricultural production and the consumption of individual types of meat in Czechia. Using Holt's model of statistical analysis, it then predicts the future consumption of meat and its individual types in the Czech Republic in the years 2020-2024. As research has shown, the sustainable development of livestock production and meat consumption in the Czech Republic depends not only on the mutual size of meat production and consumption or its quality, but also significantly on the market prices of meat (including world prices), as well as changes in eating habits of the population.
\end{abstract}

Keywords: agribusiness; agriculture; degree of self-sufficiency; livestock; livestock production; meat; meat consumption; subsidies; sustainability

\section{Introduction}

Agriculture is one of the basic branches of the national economy. Sustainable agriculture involves obtaining healthy and quality foods, conserving natural resources and preserving biodiversity [1]. Agriculture sustainability assessment is conducive to promoting sustainable agriculture construction and sustainable development. Modern agriculture and modern small-peasant production have different requirements for agriculture sustainability [2]. In scientific literature with a focus on economics, the topic of sustainability has proven to be a relevant area of research in the last decade. Particularly in connection with the food industry, the issues of corporate social responsibility [3].

Sustainable development is one of the main objectives of the European Union [4]. According to its principles, the economic aspect of the development should perceive society and the natural environment not as its inhibitors but rather as stimulants [5]. Sustainable development in agriculture means such programming of farming production so that it makes reasonable use of natural resources and the environment. It provides sufficient amounts of food while maintaining its high quality [6].

Innovation and sustainability are key driving forces of modern food production chain, which require an accelerated transfer of new knowledge generated by fundamental and applied research in food as well as other adjacent scientific domains [7]. Although 
agriculture, which is part of the whole food system (i.e., from farm to fork), potentially influences nutrition outcomes, current commercial food value chains are often developed without a clear inclusion of nutrition objectives (i.e., nutrition sensitivity) [8].

Agriculture in Czechia is one of major sectors of the economy, as it provides an essential share of the basic food requirements of the population. An important part of agricultural companies' production consists of livestock, especially because of the effective use of crop production as a source of all kinds of animal feed. For example, Mathias [9] studied the environmental impact of intensive livestock production systems. It is also proven that livestock production plays a significant role in the creation and cultivation of the landscape [10].

Meat and meat products are frequently overconsumed in the diets of developed countries [11]. According to the Food and Agriculture Organization of the United Nations [12] meat remains the main global protein source with animal protein demand expected to increase in coming years [13]. Despite advances in development of alternative protein sources (plants, algae, etc.) the demand for high quality meat proteins is increasing due to growing world population [14]. However, as the environmental awareness of consumers rises, the demand of environmental friendly food products grows too [15].

Although meat represents the basic source of animal protein and contains significant amounts of vitamins and minerals, these foods also include fat, especially saturated fatty acids (SFA), which several authors concur, could represent an effective risk for the consumer health $[16,17]$. In recent years, consumers have demonstrated a great interest in food formulated with ingredients considered beneficial for health or that reduce components deemed unsafe $[18,19]$.

The quality of meat and its dietetic value and health-promoting properties are becoming increasingly important in conscious and rational human nutrition [20]. Consumers frequently demand healthy and high-quality meat products that are low in salt, fat, cholesterol, nitrites and calories. In addition, they are increasingly soliciting products containing health-promoting components such as unsaturated fatty acids and fibers [21].

Currently, an increased interest in qualitative parameters of pork meat has been recorded. Consumers require tasty and healthy products of local origin [22]. Food quality and food safety became important issues in the last decade. People and governments really pay attention to what they produce and consume. This situation has led to the establishment of national and international standards and laws for food products in order to protect consumers $[12,23,24]$.

Bonneau et al. [25] state that farm-level pork production in the EU is influenced by intensive production systems involving environmental and animal welfare; some countries are not economically competitive on the world market and the diversity of production systems is threatened due to the economic pressures exerted by society and consumer demands. The author identifies two main clusters of conventional systems: one that can be identified as intensive, supplying the standard meat market (Germany, France, south and middle European states), and another which is also intensive but clearly welfare oriented (mainly encountered in The Netherlands and Nordic countries).

The research gap that should be filled by the following article is a mutual comparison of production and consumption of different types of meat in the Czech Republic using statistical analysis of data in terms of sustainable development of livestock production in a given locality. An important part of the solution is also the analysis of the Czech Republic's self-sufficiency in individual types of meat, possibly its foreign exchange.

The aim of this article was to express social and economic aspects of the sustainable livestock production in relation to meat consumption in the Czech Republic and to predict, through statistical analysis, the possibilities of further development of the field of livestock production in the conditions of Czech agriculture. 


\section{Materials and Methods}

\subsection{Methodology}

The methodology used for writing this article is based on a description of development in the production of individual types of meat in Czechia and on an evaluation of the relationship between the production results of the agricultural sector and the production of primary livestock production categories. Through a comparative analysis, the possibilities of increasing the self-sufficiency of Czechia in the production of meat and meat products are analyzed.

This article is based primarily on:

- an evaluation of statistical data published by the Czech Statistical Office (CZSO) on the production of the individual meat types in the Czech Republic in the period 2000-2019;

- an evaluation of statistical data published by the Czech Statistical Office (CZSO) on the consumption of the individual meat types in the Czech Republic in the period 2000-2018;

- identification of factors threatening the sustainable development of livestock production and meat consumption;

- an assessment of the incentive factors that will lead to a growing interest of Czech farmers in increasing the production of meat and meat products;

- a description of the necessary legislative changes by the state that would allow sustainability or possibly an increase in the share of the local production of meat and meat products for the consumption of households in the Czech Republic.

The euro currency unit (26.15 CZK/EUR as of 30 November 2020) was used for the purpose of expressing financial amounts in the article.

In order to evaluate the goal achieved, statistical analysis tools were used to determine the development of meat production and consumption, correlation between time series of selected indicators and to create models for predicting the consumption of basic types of meat. The conclusions of the solution will provide answers to the hypothesis about the changing role of livestock production in the agricultural production of the Czech Republic.

For time series modeling, it was assumed that each previous value of the time series has an immediate effect on the next value and that the value immediately preceding has greater significance than the older value. Therefore, the method of exponential smoothing, of the second degree (Holt's method), extended by a damped trend was used for the predictions. It is an extension of the original method by a coefficient that dampens the linear trend towards a value to which the series tends to converge in time. The model is thus extended by the phi constant, which has the task of damping the linear trend. A model with M.A.P.E. (mean absolute percentage error) values below $5 \%$, or below $10 \%$ was chosen as a suitable time series model for series prediction and description. The coefficients of the model were estimated based on the minimization of the above-mentioned M.A.P.E. indicator.

Furthermore, the relationship between the time series of the selected indicators was investigated. For this, the method of correlation of time series was used, when a pair correlation coefficient was calculated for the investigated time series, which allows the investigation of the causal relationship between the variables. The article works with the residues of each time series:

$$
e_{x}=x_{t}-x^{\prime}{ }_{t} \text { and } e_{y}=y_{t}-y^{\prime}{ }_{t}
$$

where $x^{\prime}{ }_{t}=f(t), y^{\prime}{ }_{t}=f(t), t=1,2, \ldots, n$.

This makes it possible to verify whether the deviations $e_{x}$ and $e_{y}$ are arranged randomly in time and whether there is a relationship between them. The intensity of the dependence of the time series of the two indicators was determined using the correlation coefficient of the residual deviations. As Hindls et al. [26] stated, the correlation coefficient is determined by the relationship: 


$$
r_{e_{x}, e_{y}}=\frac{\sum_{t=1}^{n} e_{x} \cdot e_{y}}{\sqrt{\sum_{t=1}^{n} e_{x}^{2} \cdot \sum_{t=1}^{n} e_{y}^{2}}}
$$

Hypothesis 1. Although meat production in the Czech Republic is significantly affected by imports from abroad and at the same time exports abroad (especially in pork and beef), sustainable meat consumption depends mainly on the consumer habits of the population and significant fluctuations in the market prices of meat.

\subsection{Performance of Czech Agriculture}

In 2018, domestic agriculture experienced an extraordinary drop in profits. The total profit, which includes the results of plant and livestock production, was EUR 660 million in 2018 according to the CZSO [27]. It was thus 20\% lower than in 2017. The profits in 2016 and 2017 exceeded EUR 800 million (see Figure 1).

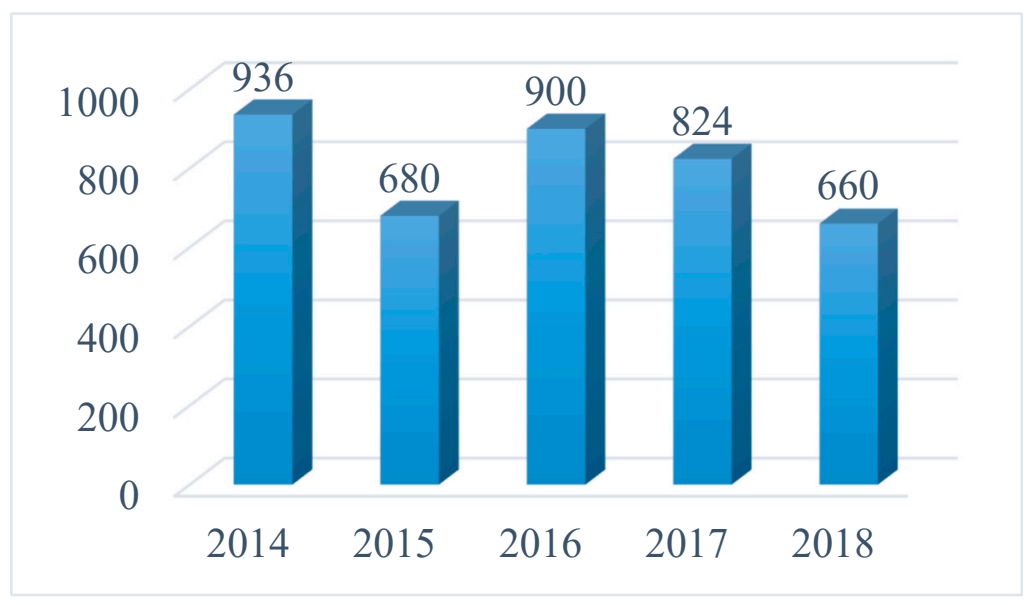

Figure 1. Agricultural profit in the Czech Republic (EUR millions) [27].

Both the Agricultural Association and the Association of Private Farming consider the result of 2018 to be a truly extraordinary fluctuation and see the drought as the main culprit. It causes most plant commodities to fall; at the same time, feed prices increased, which meant an increase in livestock production costs. In 2018, feed prices increased by $7 \%$ year-over-year according to the CZSO [27].

The decline in the crop production is undoubtedly related not only to weather fluctuations, but also to the effects of climate change on the landscape. Farmers need to rotate crops and reduce large areas of fields to prevent erosion. The construction of borders and draws is also important.

As regards crop production, the most important crops are wheat and rapeseed. The drought does not have a significant effect on rapeseed, which is sown at the end of summer. On the other hand, the amount of cereal harvested in 2018 was almost $8 \%$ less than it was in 2017 and the yield per hectare fell by 6.7\% year-over-year. This led to an increase in the price of not only cereals themselves, but also other commodities. Thus, the value of agricultural production increased by 1.2\% to EUR 5404 million in 2018 (see Figure 2). 


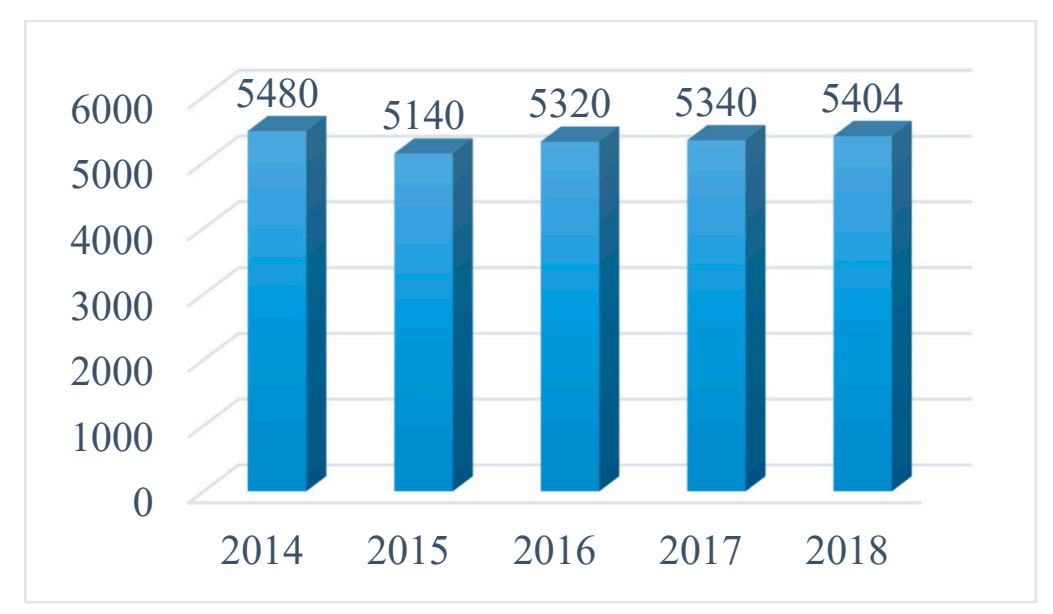

Figure 2. Value of agricultural production in the Czech Republic (in EUR millions) [27].

The results of Czech agriculture are also getting worse due to the rising prices of energy, usufructuary leases and rents and labor. There is a shortage of workers, and wages are increasing. This means that not even agricultural companies that have the prerequisites to do so can grow or actuate. According to the statistics, the wages of employees in agriculture increased by $4.4 \%$ year-over-year in 2018 [28].

Furthermore, the text of the article focuses mainly on the social and economic aspects of the sustainability of livestock production in relation to meat consumption in the Czech Republic.

\section{Results}

\subsection{Meat Production in the Czech Republic}

By meat we mean all parts of livestock that are edible and intended for human consumption. We also distinguish meat products. Meat products are technologically processed products of which meat is the main component [29]. Meat production in the Czech Republic increased slightly in 2019 compared to 2018 by $0.4 \%$ to 450.8 thousand tons. Pork production has decreased, but it accounts for almost half of the country's annual meat production. Pork is one of the mainstays of the Czech diet. Table 1.

The structure of meat production in the Czech Republic is shown in the following

Table 1. The structure of meat production in the Czech Republic in 2018 [27].

\begin{tabular}{ccc}
\hline & Production in Tones & Share of Meat Production \\
\hline Pig meat production & 210,910 & 47.3 \\
Beef and veal meat production & 71,579 & 16 \\
Poultry meat production & 164,261 & 36.7 \\
Other meat & 260 & 0 \\
In total & 447,010 & 100 \\
\hline
\end{tabular}

Meat production in the Czech Republic decreased significantly in the years 2000-2018 from 703,052 tons to 447,010 tons in 2018, i.e., by 36.42\% less (see Figure 3). Production decreased in all three main types of meat, but most in pork, from 396,107 tons to 210,910 tons, i.e., by $46.75 \%$ less. 


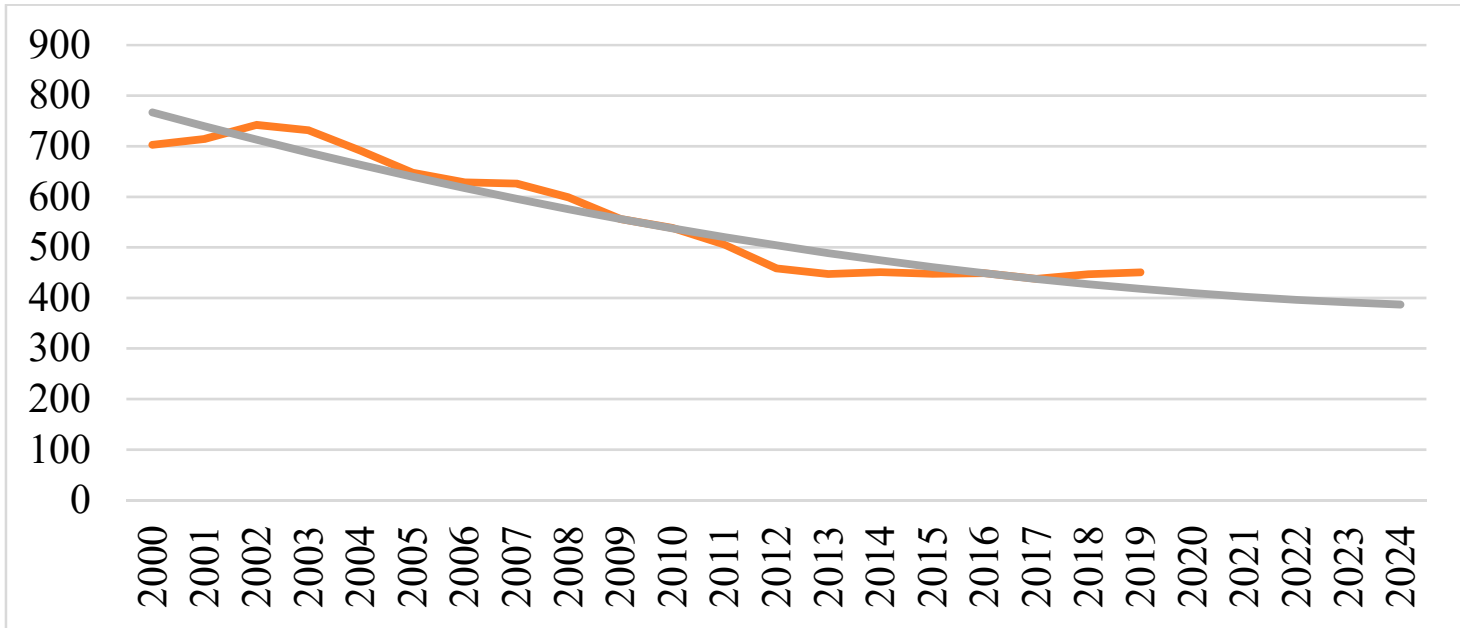

Figure 3. Total meat production in the Czech Republic in the years 2000-2019, including a forecast for five years ahead (in thousands of tons) (silver line represents prediction; red line represents observed data) [27].

\subsubsection{Pig Meat Production}

Market prices of pork have recently been on the rise, both in the Czech Republic and worldwide. Pork has risen in price due to swine fever, which has caused a sharp decline in pork production in China. Due to the forced slaughter of large quantities of livestock, exports from the European Union to China, especially from Germany, Spain and Denmark, increased dramatically in 2019, pushing meat prices to record highs at the end of 2019 and February 2020. Since mid-March 2019, the prices of pigs processed at slaughterhouses have gone up by approximately a fifth, while individual, separately traded pig carcass parts have seen an increase of up to $40 \%$ in the Czech Republic. The rise in prices is due to both the higher proportion of meat being sold to China and the failure of meat processing plants to reduce their prices in the past, when pigs were being marketed for less than the cost of processing them. As numerous farmers were forced to close down their production and lost all of their pigs as a result, the prices continued to go up [30]. The increased price of pork was felt by end consumers already at the turn of 2019/2020. Between the turn of the millennium and March of 2019, the number of farmed pigs dropped from nearly 3.69 million down to 1.54 million according to the Czech Statistical Office [27].

However, the supply of the world pork market may deteriorate in 2020 because US slaughterhouses have stopped production due to the spread of coronavirus among employees. A total of about twenty slaughterhouses were closed, raising concerns about meat shortages around the world.

According to data from the CZSO [27], 2.4 million pigs were slaughtered in slaughterhouses in 2017, namely $3.7 \%$ less than in 2016. The prices of producers of pigs for slaughter increased by $11.1 \%$ in 2017; the average price per kilogram of live fattened pig was EUR 1.30.

In 2017, imports of pig meat rose by 1.5\% year-on-year. It was imported mainly from Germany, Spain, Poland and Belgium, and it was exported mainly to Slovakia. Young pigs made up the larger portion of imports, and pigs for slaughter made up the larger portion of exports. The foreign trade of the Czech Republic with pig meat is also documented by the following data [31]:

- $\quad 283,787$ tons of pig meat were imported into the Czech Republic in 2017;

- $\quad 35,598$ tons of pig meat were exported, in particular to Slovakia.

Pork production in the Czech Republic has seen a significant declining trend since 2004. Pork production in the Czech Republic reached its minimum in 2019 (Figure 4). 


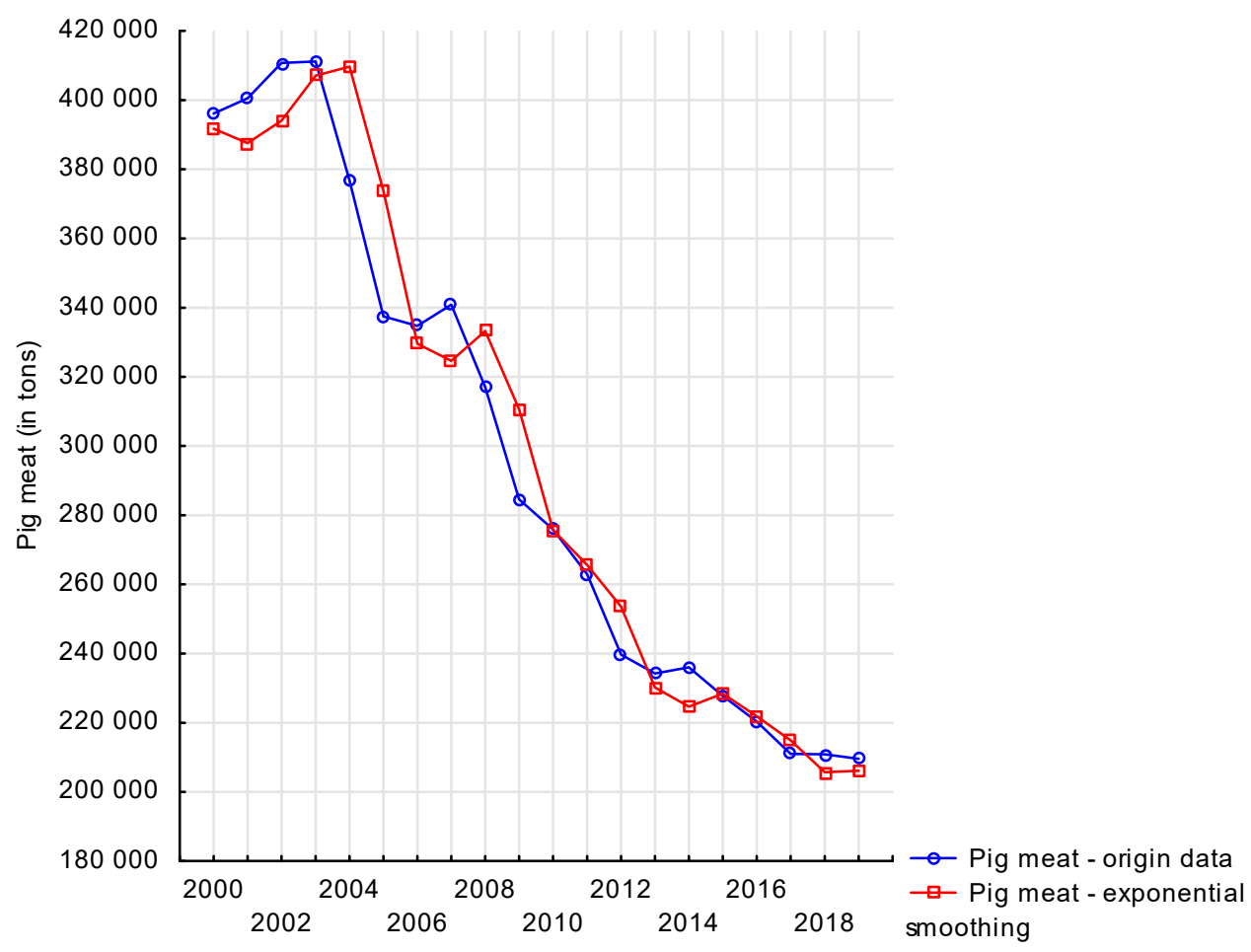

Figure 4. Pig meat production in the Czech Republic in long term time series (in tons) [27].

In 2015 , the long-term trend led to a decrease in the self-sufficiency rate of pork to $53 \%$ (see Figure 5), while for other agricultural products it reached more than $80 \%$. Following the ban on pork exports into Russia, purchase prices in the Czech Republic have also begun to fall since the end of 2014, falling below the critical threshold of EUR 1.20 per kilogram. According to the data of the Agricultural Association of the Czech Republic [32], in 2015 breeders sold pork to meat processors more than 8 cents below production costs. One of the reasons for the current increase in the price of pork is also the low self-sufficiency in its production, which in 2018 amounted to 51.2\% in the Czech Republic (see Figure 5). The estimate calculated by the Czech Ministry of Agriculture for 2019 is even lower, amounting to $50.7 \%$ [31].

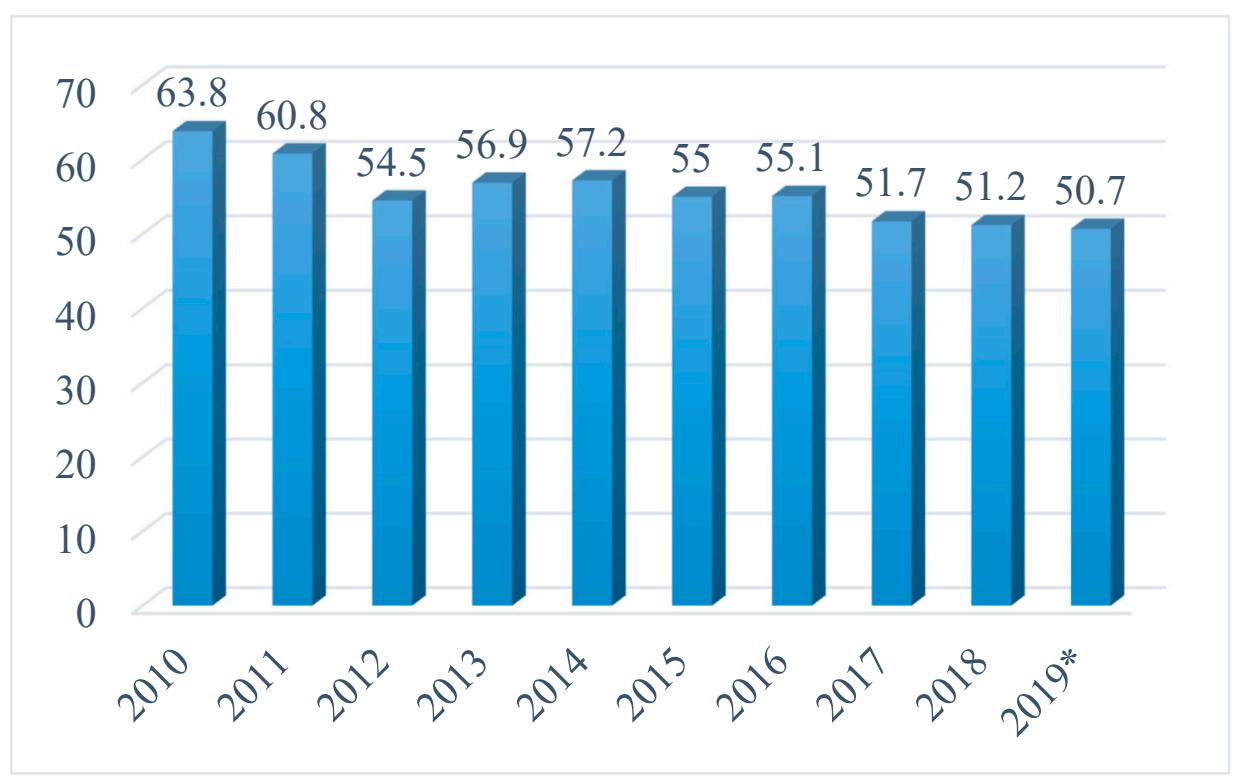

Figure 5. Czech self-sufficiency rate with regard to pig meat (in $\%)\left({ }^{*}\right.$-prediction) [30]. 


\subsubsection{Beef and Veal Meat Production}

In 2019, beef and veal production increased by 1.8\% year-on-year [27] (see Figure 6). The lowest production was in 2014, when the level of own production was only 65 thousand tons. Although imports of animals for slaughter increased in 2017, domestic beef production did not reach the level of the previous year and was replaced by increased imports of beef from abroad. In 2016, the prices of producers of cattle for slaughter were $2.3 \%$ higher than they were in 2017. In 2017, the average purchase price per kilogram of live bull was 7.27 cents. As in the case of pork, more beef was imported than exported. It was imported to the Czech Republic in particular from Poland, the Netherlands and Germany [27]:

- the total amount of beef imported from abroad was 37,283 tons;

- the total amount of beef exported abroad was 10,322 tons.

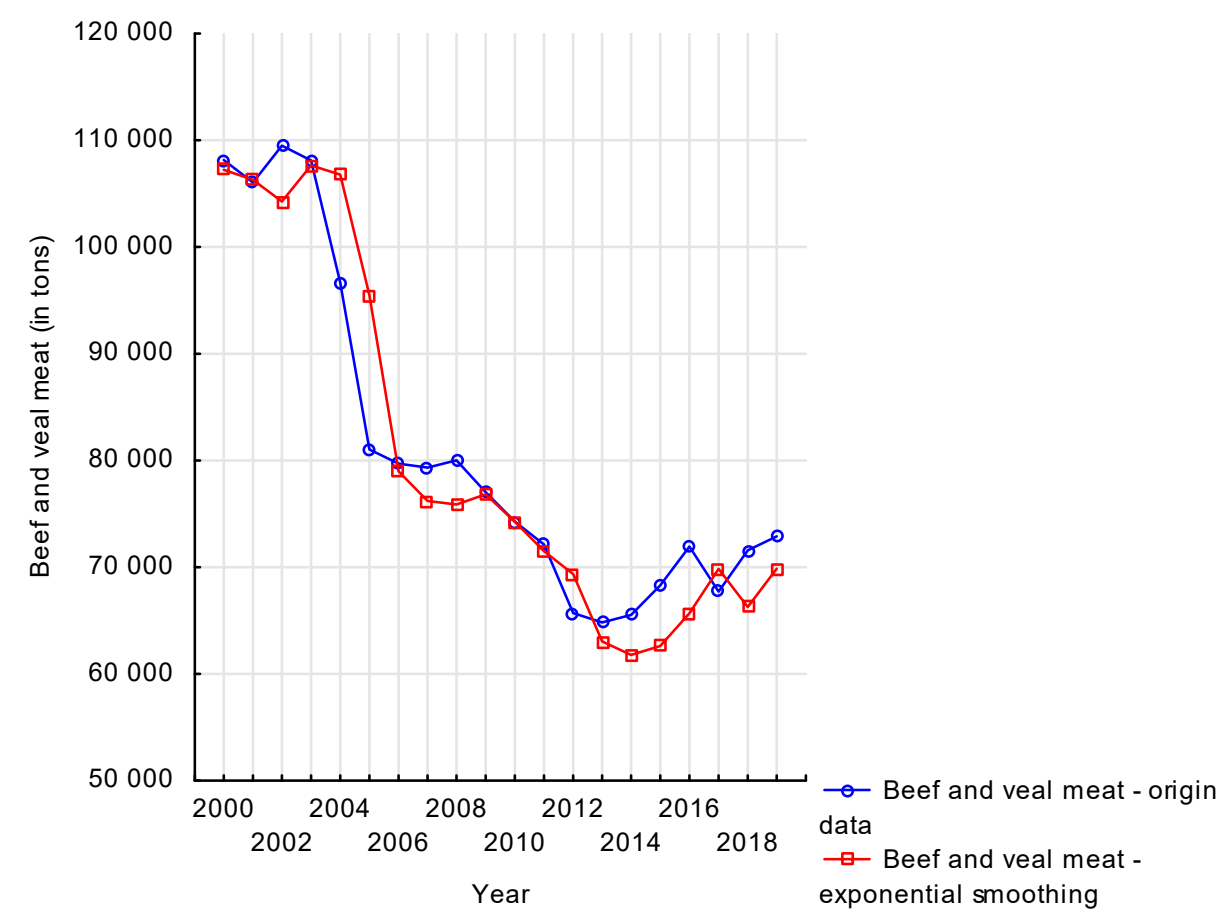

Figure 6. Beef and veal meat production in the Czech Republic (in tons) [27].

The domestic beef market is in conflict. According to the Czech Confederation of Commerce and Tourism [33], Czech producers are capable of ensuring the country's selfsufficiency in beef production. The Ministry of Agriculture [31] quantified this capability at $122.4 \%$ in 2018. In 2013, the Czech Republic's self-sufficiency in beef production was as much as $140.1 \%$, rising by almost nine percentage points year-over-year. While 81,000 tons of live cattle worth EUR 180 million was exported in 2018 (see Figure 7), nearly 38,000 tons of fresh, chilled or frozen beef of the same value was imported (see Figure 8). The largest proportion of meat processed in this manner was imported from Poland, namely 11 thousand tons worth almost EUR 40 million [27]. 


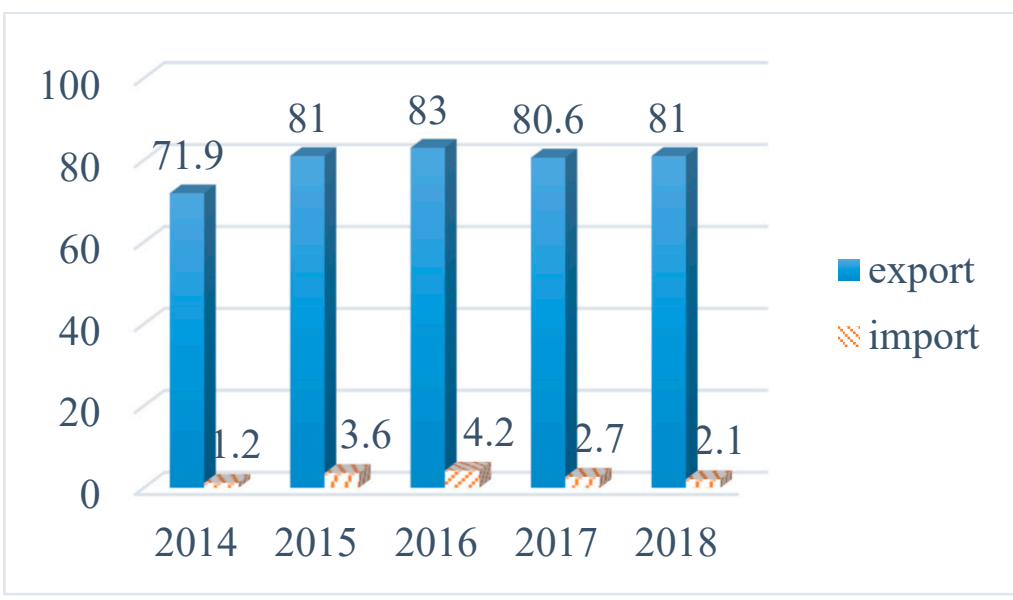

Figure 7. Live bovine animal trade (in thousands of tons) [27].

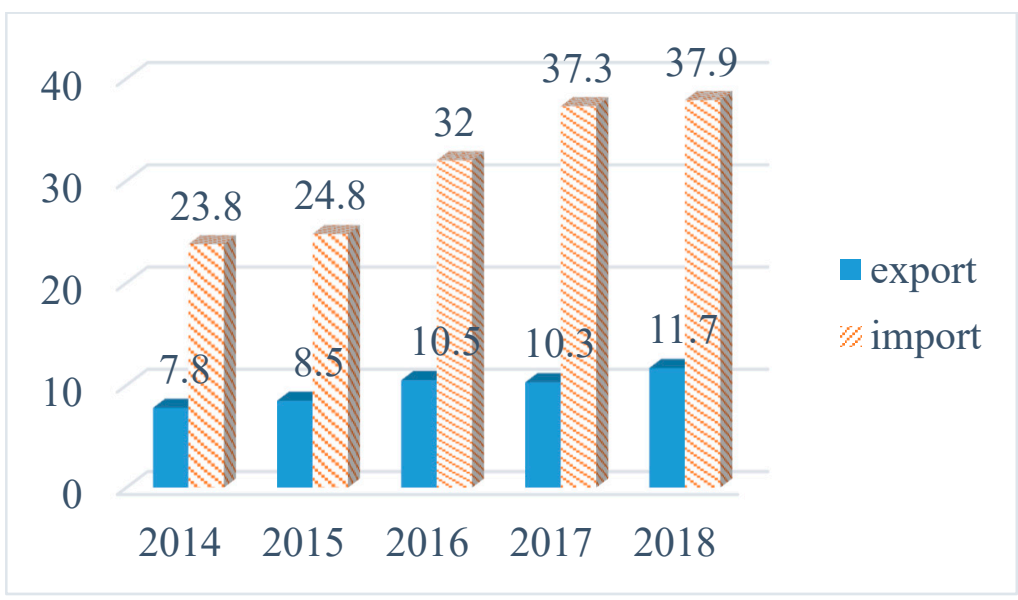

Figure 8. Beef trade (in thousands of tons) [27].

According to the Czech Meat Processors Association [34], the main issue lies with the processors. In the Czech Republic, the processing capacities available are not being fully utilized. In addition, there is a shortage of trained butchers at slaughterhouses in the country, with around 5000 missing on the labor market. The Association also attributes the unbalanced situation in the beef market to the fact that breeders get a more favorable price for live cattle on the foreign market.

The Czech farmer naturally seeks the best possible price for his animals. The Czech Beef Breeders Association admits that domestic breeders sell animals, for example, to Turkey at a favorable price. Eight thousand tons of live animals worth EUR 25.72 million were exported to Turkey in 2018. Even larger quantities of cattle were exported to Austria and Germany in 2018 [35].

The domestic demand for cattle is not high enough. There is not enough interest in cattle from domestic entrepreneurs, because there are pressures in the Czech Republic for the price of beef to be as low as possible. Cheap meat is not always of a good quality, as the recent affair with the import of spoiled beef from Poland has shown.

\subsubsection{Poultry Meat Production}

In 2019, the Czech Republic produced 168,000 tons of poultry meat, i.e., the yearon-year increase was $1.02 \%$ higher (see Figure 9). In 2017, the Czech Republic produced 159,000 tons of poultry meat, and production thus increased by $1.5 \%$ year-on-year. Both imports and exports dropped; imports decreased by 2.3\% to 116,785 tons in 2017 year-over- 
year and exports decreased by $7.2 \%$ to 34,372 tons [27]. Poland was a major exporter of poultry meat to Czechia.

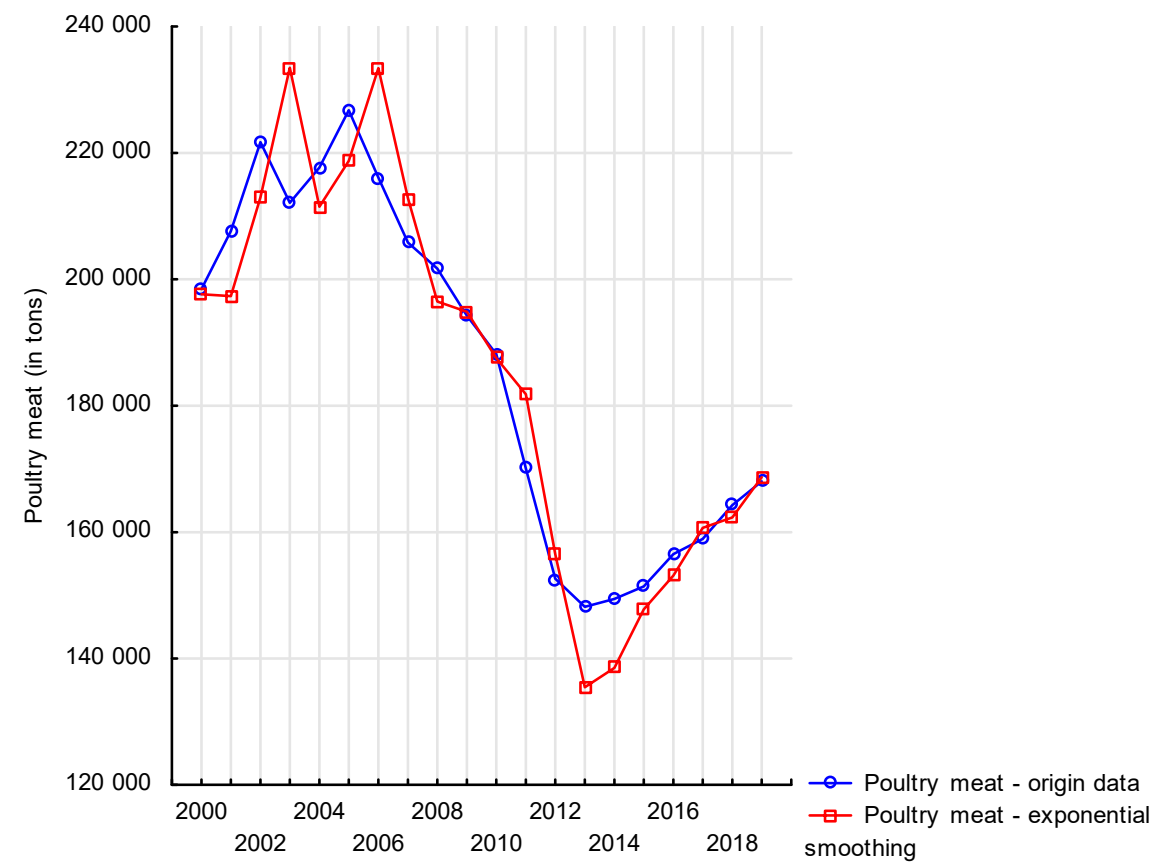

Figure 9. Poultry meat production in the Czech Republic (in tons) [27].

Czech self-sufficiency rate with regard to poultry meat was 55\% in $2017 ; 45 \%$ was imported from abroad (mainly from Poland).

\subsubsection{Sheep and Goat Meat Production}

In 2019, there was a decrease in the production of sheep and goat meat, which is marginal in the Czech Republic and reached the level of only 223 tons.

\subsubsection{Relationship between Pork, Beef and Poultry Production}

Table 2 is based on residual data of the time series of the production from the years 2000-2019 and on adjusted values calculated by the method of exponential smoothing. The results of the calculations show an intense positive relationship between pork and beef production in the Czech Republic and confirm a certain stability of the structure and character of livestock production in Czech agriculture. Poultry farming is a marginal issue for Czech primary producers.

Table 2. Relationship between pork, beef and poultry production.

\begin{tabular}{cccc}
\hline Variable & Pig Meat Production & $\begin{array}{c}\text { Beef and Veal Meat } \\
\text { Production }\end{array}$ & Poultry Production \\
\hline Pig meat production & 1.000000 & 0.754792 & -0.107706 \\
Beef and veal & 0.754792 & 1.000000 & -0.066815 \\
production & -0.107706 & -0.066815 & 1.000000 \\
Poultry production & & & \\
\hline
\end{tabular}

\subsection{Meat Consumption in the Czech Republic}

From an economic point of view, consumption can be expressed as the use of products or services to satisfy human needs. 


\subsubsection{Share of Meat Consumption in the Czech Republic}

In the following part of this article, meat consumption in the Czech Republic will be analyzed. Consumption data from 2000 to 2018 will be examined. In 1989, there was a significant change in economic and social conditions in the country, and it can be assumed that these changes were gradually reflected in the preference for certain foods, including meat. The analysis was performed on the basis of data from the Czech Statistical Office [27].

Figure 10 shows the share of meat consumption in 2000. As can be seen from the graph, most of the meat consumed was pork. Pork accounted for $51.2 \%$ of the total share of meat consumed. In total, there was an average of $40.9 \mathrm{~kg}$ of pork per person in 2000. This year, the annual consumption of beef was $12.3 \mathrm{~kg}$ per person, which represented only $15.1 \%$ of the total meat consumption. In 2000, each person consumed an average of 22.3 $\mathrm{kg}$ of poultry meat, with the vast majority being chicken. The share of poultry meat in total meat consumption in 2000 was $28.1 \%$. In the case of other types of meat, it was only a marginal matter.

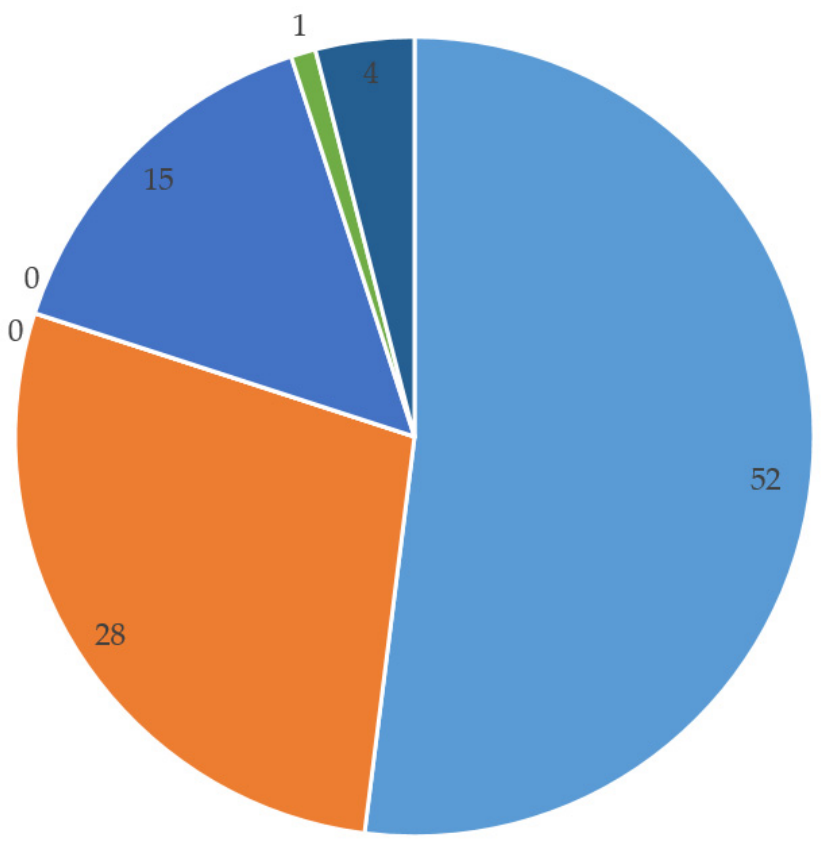

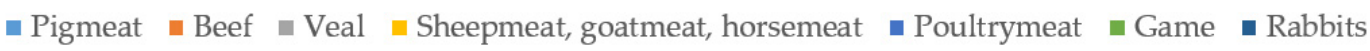

Figure 10. Share of meat consumption in 2000 in \% [27].

Figure 11 shows the total meat consumption in the Czech Republic in the years 2000 to 2018. As can be seen from the graph, meat consumption increased in 2002-2007, but since 2008 meat consumption has decreased as a result of the economic crisis and thus household consumption. Consumption did not increase until 2014. In 2000, the total meat consumption per person in the Czech Republic was $79.4 \mathrm{~kg}$, in 2018 it was $82.4 \mathrm{~kg}$. 


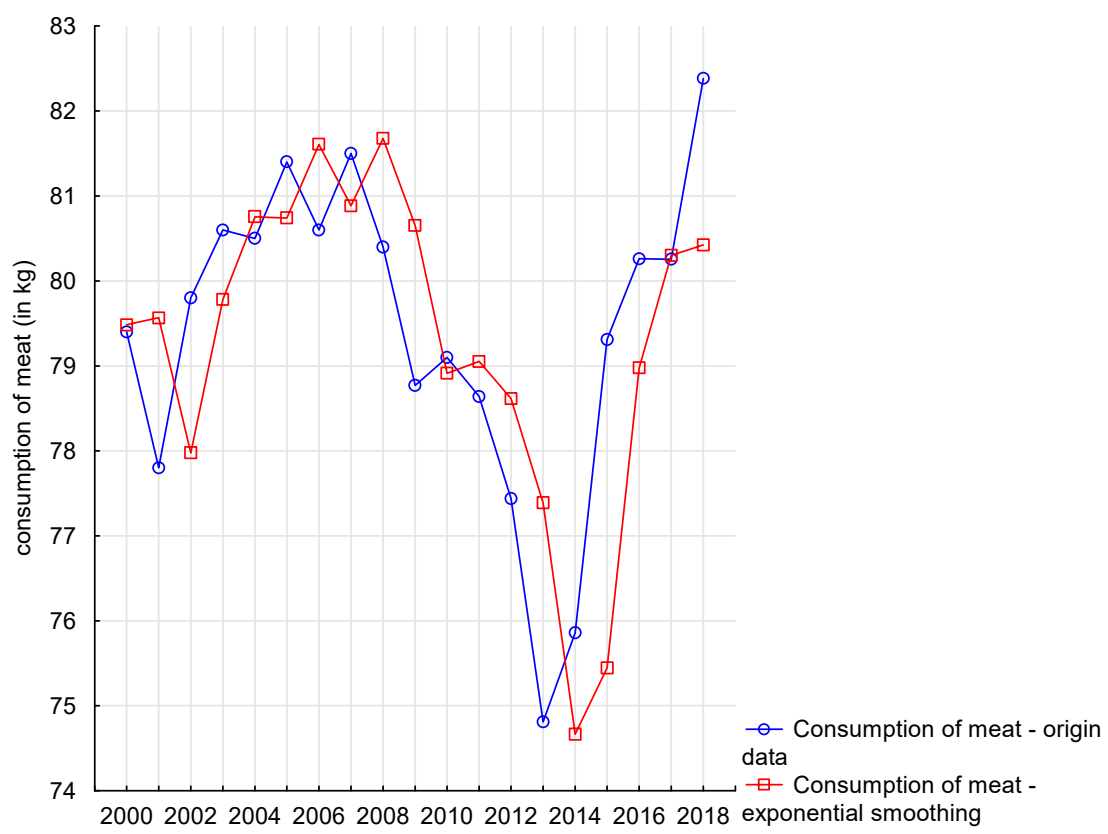

Figure 11. Total meat consumption between 2000 and 2018 [27].

\subsubsection{Share of Individual Types of Meat in Its Total Consumption}

The structure of meat consumption by main commodities is shown in Figure 12. The graph is based on a database from 1989-2018 and shows the consumer's shift from traditional types of meat (pork and beef) to healthier poultry meat.

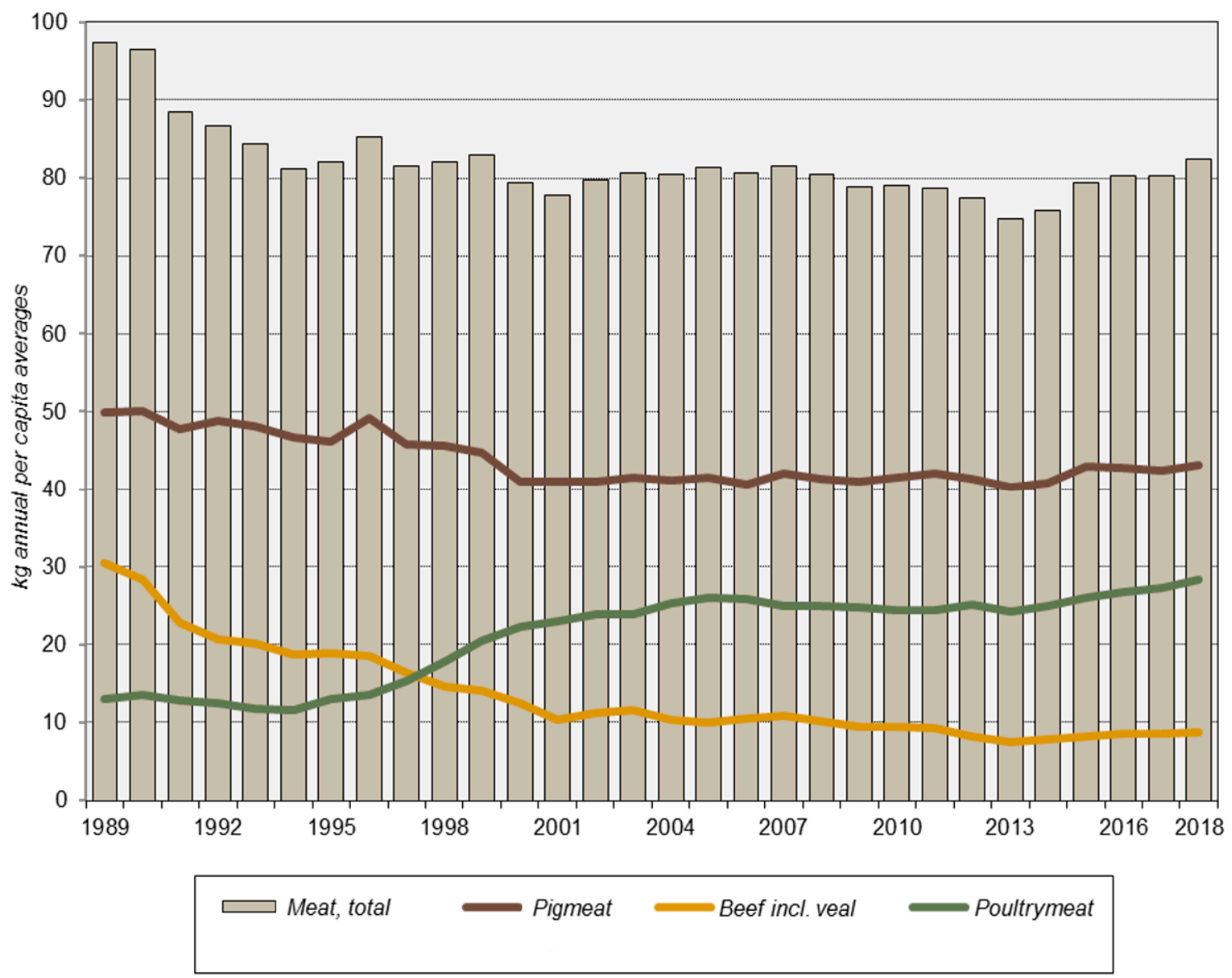

Figure 12. Share of pork, beef and poultry meat in its total consumption in the years 1989-2018 (kg/person) [27]. 
Figure 13 shows the share of consumption of individual types of meat in the total consumption of meat in 2018. As can be seen from Figure 13, the share of consumption of veal, mutton, goat and horse meat is similar in 2000. The consumption of game recorded a slight increase, but there was a large decrease in the consumption of rabbit meat (a decrease of $80 \%$ ). The traditional countryside with small livestock farms has disappeared from Czech agriculture.

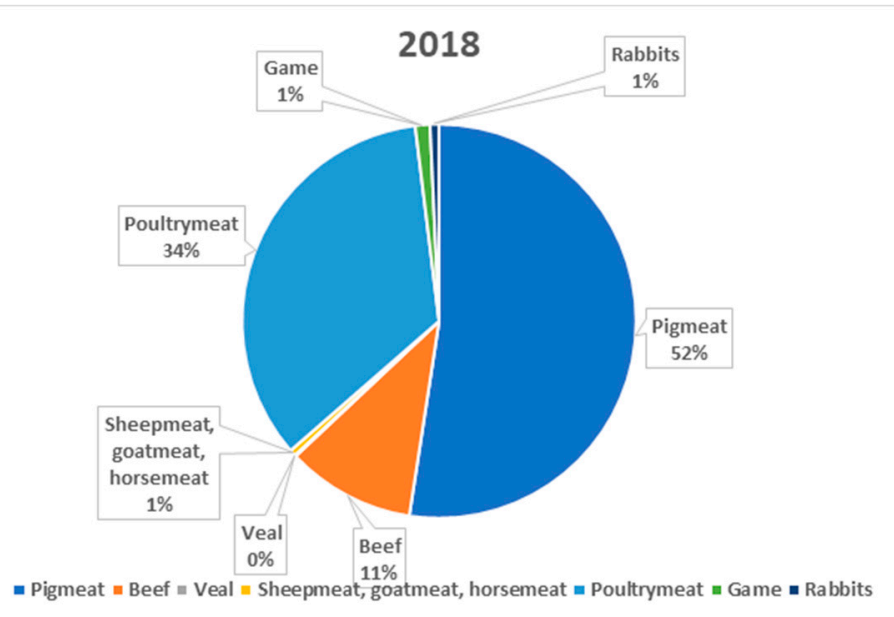

Figure 13. Share of meat consumption in 2018 [27].

\subsection{Changes in Meat Consumption in the Czech Republic}

What are the main reasons for the change in meat consumption in the Czech Republic? According to information from retail chains [36], the Czech customer likes to buy at a promotion price. Up to half of the entire range offered by retail chains is sold at a discount. Research by the Ministry of Agriculture of the Czech Republic [30] also found price orientation to be the main trend in the development of meat consumption. However, the origin of meat also played a role. Consumers were looking for the information on the kind of breeding the meat came from and the conditions the animal lived in [37].

However, Kameník [38] also points to the fact that the Czech consumer is not oriented only by the price, but also by other aspects, which are mainly the health effects of the given type of meat. Therefore, according to the authors of the article, white (poultry) meat is more popular than red meat (pork and beef). According to experts, white meat is much healthier because it contains less fat and the human body can make better use of the proteins contained in this type of meat. However, the author does not deny that the great advantage of poultry meat, especially chicken, is its low price, which is given by the cost of primary production [38].

Table 3 shows the results of the correlation analysis performed in the Oliinyk study [39] to determine the relationship between price and consumption of individual types of meat. As is clear from the table, there is a situation where if the price of pork meat increases, its consumption also increases slightly $(r=0.227)$. In the case of beef, the situation is the opposite, if the price increases, its consumption decreases $(r=-0.735)$. It can therefore be said that in the case of beef, the main factor influencing trends in its consumption is, in particular, price. While in the case of pork there are other factors. Here it can mean especially a change in lifestyle. Štiková et al. [40] from the Agricultural Economics Research Institute came to a similar conclusion.

Price is generally an important factor for most consumers' decisions. It is precisely with beef that with the interest in other types of meat and the suppression of beef consumption, its price is rising. This is not a surprising finding. Cattle breeding is generally a relatively expensive affair. If a farmer wants to be profitable, he/she has to react to changes in demand in a certain way. This may be by trying to sell more meat or making the meat more expensive. 
Table 3. Correlation analysis of the relationship between price and consumption of individual types of meat.

\begin{tabular}{ccccc}
\hline & Price of Pork & Price of Beef & $\begin{array}{c}\text { Consumption } \\
\text { of Pork }\end{array}$ & $\begin{array}{c}\text { Consumption } \\
\text { of Beef }\end{array}$ \\
\hline Price of pork & 1 & & & \\
Price of beef & 0.888 & 1 & & \\
Consumption of pork & 0.227 & -0.035 & 1 & 1 \\
Consumption of beef & -0.909 & -0.735 & -0.014 & 1 \\
\hline
\end{tabular}

The Czech Meat Processors Association [34] gives the following reasons for the decline in interest in beef:

(a) The impact of BSE (Bovine spongiform encephalopathy) disease in cattle is overestimated;

(b) the quality of the beef offered is relatively low, but above all unreliable, non-standard. In this sense, beef loses in competition with pork and poultry;

(c) the consumer appreciation of the "quality-price" relationship is worse for beef than for the other two main types of meat. Chicken meat is the best from this comparison;

(d) on the market, beef from older pieces is exchanged for younger meat. Such an experience will discourage consumers from the next interest in beef;

(e) economic reasons (lack of refrigeration capacity, weight loss during cold storage of meat) lead to premature dispatch of meat and thus to its insufficient maturation and failure to achieve the expected culinary and sensory quality.

From the above, it is clear that the main reason why the consumer does not buy beef is mainly its low quality, which does not correspond to the price. At least that is what the Czech Meat Processors Association states. It is possible that, for example, the fear of BSE disease may be behind the decreased popularity of beef, but also the relatively demanding preparation, as most consumers have probably gotten beef on a plate that was too tough to cut.

In addition, the pressure on the quality and origin of meat is still growing in the Czech Republic. This increases the amount of meat that is sold directly from the producer. Consumers also have great confidence in various quality labels and regional product labels. Thus, the aspect of where the meat comes from is becoming increasingly important. It can also be assumed that as society becomes richer and the economic and living situation of the population continues to improve, there will be an increasing emphasis on quality and guarantee of origin. Breeders and producers who do not adapt to this trend will undoubtedly have some difficulties. In addition, the Ministry of Agriculture [31] plans to make it easier for consumers in this regard. It will thus increasingly focus its attention on the support of various quality labels and regional product labels [40].

\subsection{Statistical Forecast of Meat Consumption in the Czech Republic}

The trends in meat consumption in the Czech Republic and the possible reasons behind these trends were described above. It can be assumed that the established tendencies will continue in the future. The solution focused on prognostic models of meat consumption in the Czech Republic. The forecasts are based on Holt's model with a damped trend. The choice of alpha, gamma and phi parameters is related to the amount of mean absolute percentage error. Table 4 lists the Holt's model parameters and the M.A.P.E. error for the consumption of individual types of meat, including prediction.

Figures 14-17 show the current and projected development of meat consumption for key types until 2024. The total consumption of meat in the Czech Republic shows a stable value, which should persist (Figure 14). For 2020, the total meat consumption should be $82.41 \mathrm{~kg} /$ person/year and by 2024 its size should change by only $+0.1 \mathrm{~kg} /$ person/year, i.e., by $0.12 \%$. 
Table 4. Parameters of prediction models including forecasts of meat consumption for the years 2020-2024 (in kg/person/year).

\begin{tabular}{ccccc}
\hline Parameter & Meat Total & Pork Meat & Beef & Poultry Meat \\
\hline Alpha & 0.9 & 0.9 & 0.8 & 0.85 \\
Gamma & 0.4 & 0.2 & 0.05 & 0.55 \\
Phi & 0.3 & 0.9 & 0.85 & 0.77 \\
M.A.P.E. (\%) & 1.49 & 1,56 & 6.02 & 2.22 \\
Prediction & & & 8.67 & 28.87 \\
2020 & 82.41 & 43.31 & 8.67 & 29.32 \\
2021 & 82.48 & 43.49 & 8.66 & 29.66 \\
2022 & 82.50 & 43.64 & 8.66 & 29.92 \\
2023 & 82.51 & 43.79 & 8.65 & 30.13 \\
2024 & 82.51 & 43.92 & & \\
\hline
\end{tabular}

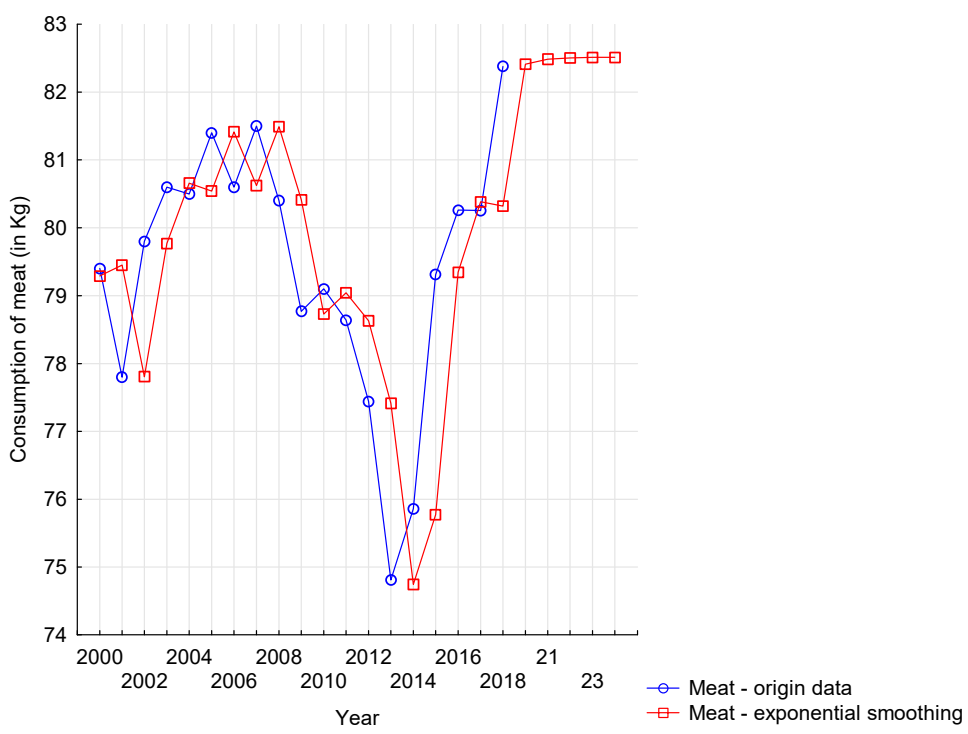

Figure 14. Prediction of total meat consumption in the Czech Republic until 2024 (kg/person/ year) [27].

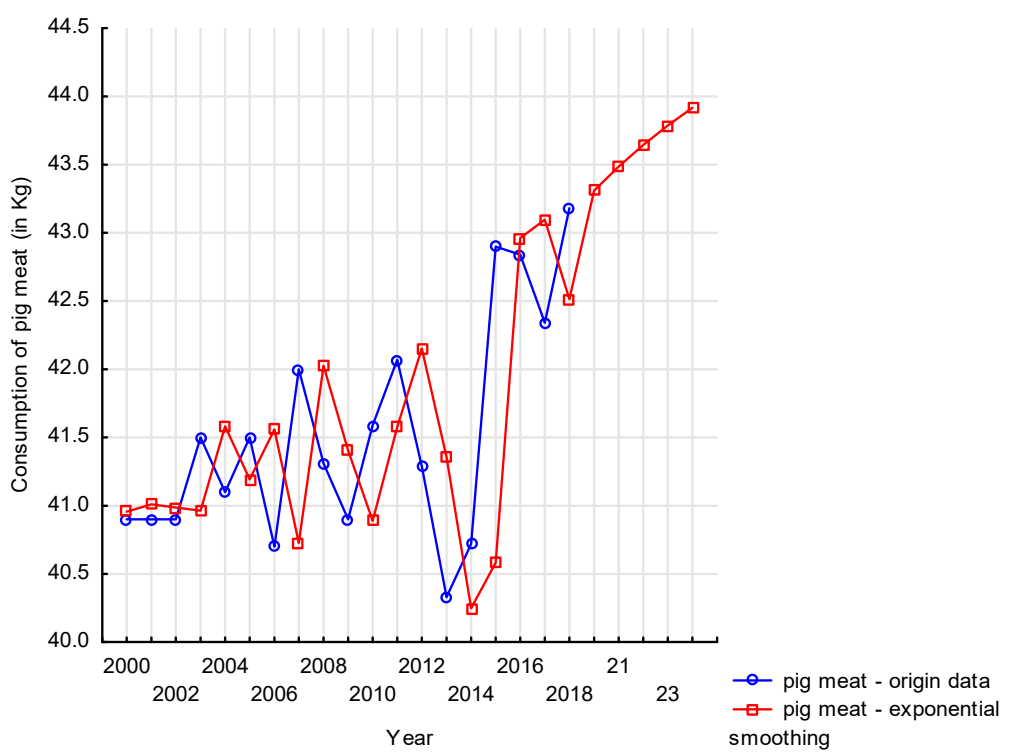

Figure 15. Prediction of pork consumption in the Czech Republic until 2024 [27]. 


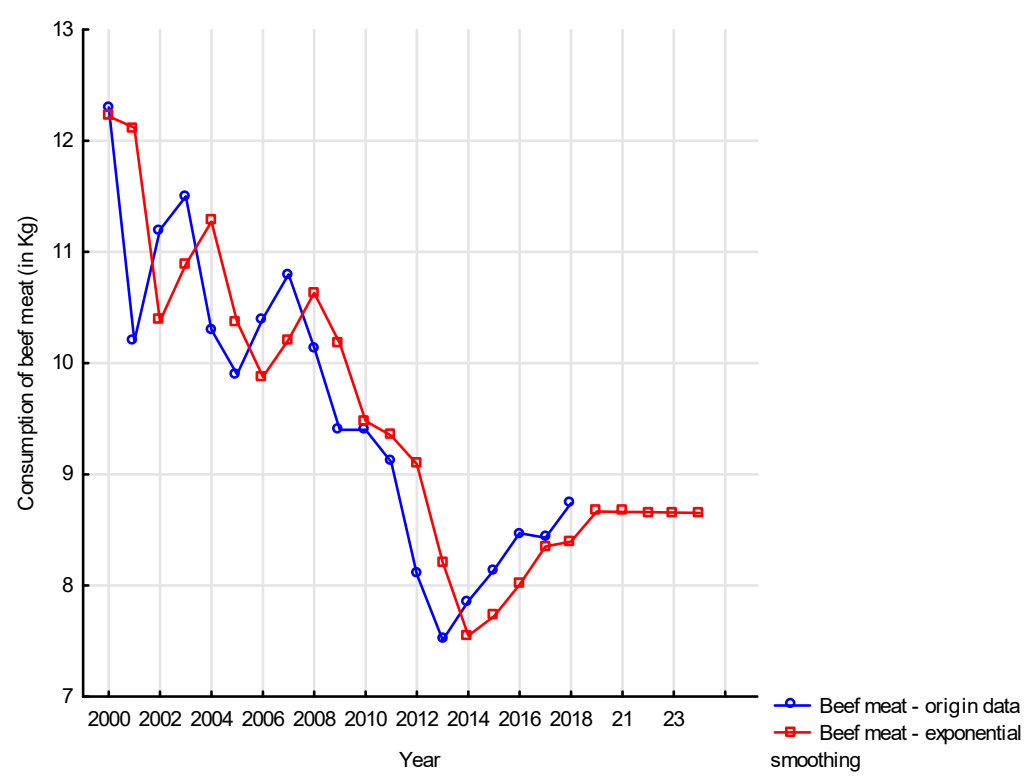

Figure 16. Prediction of beef consumption in the Czech Republic until 2024 [27].

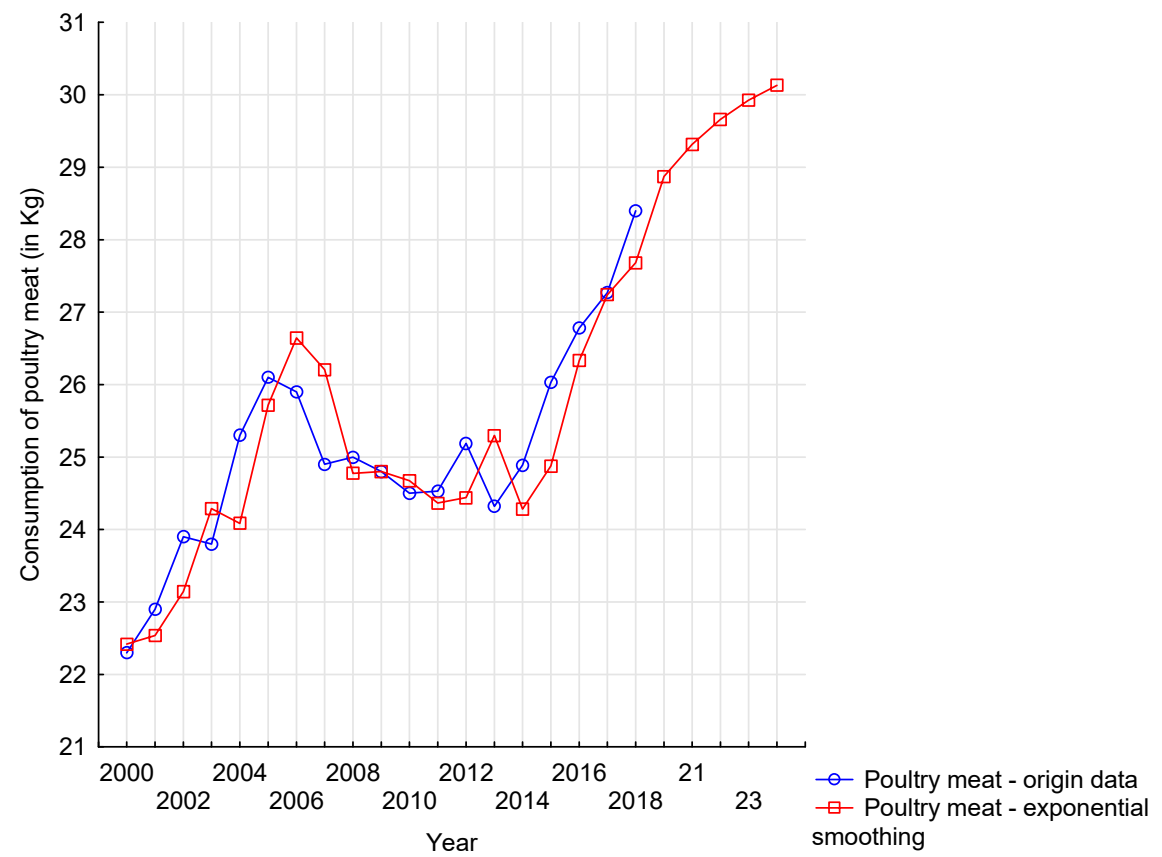

Figure 17. Prediction of poultry meat consumption in the Czech Republic until 2024 [27].

\subsubsection{Prediction of Pork Consumption}

Pork consumption shows a growing trend in the future (Figure 15). In 2024, pork consumption should increase from the current $43.31 \mathrm{~kg} /$ person/year to $43.92 \mathrm{~kg} /$ person/year, i.e., by $+1.4 \%$.

However, this aspect runs into nutritional recommendations and is related to the high incidence of obesity and diabetes in the Czech population. The Czech Republic's nutrition policy still draws attention to the need to limit the consumption of traditional pork and the possibility of replacing it with fish and game.

\subsubsection{Prediction of Beef Consumption}

Beef is too expensive for today's households and difficult to cook. Its future consumption as calculated by Holt's model is constant and should be around $8.66 \mathrm{~kg} /$ person/year 
(Figure 16) (Compared to the 2020 forecast, consumption should be lower by only $0.02 \mathrm{~kg} /$ person/year in 2024).

\subsubsection{Prediction of Poultry Meat Consumption}

Poultry meat is considered healthy by the consumer. Its consumption should continue to increase, and the model shows that in 2024 it could reach the level of $30.13 \mathrm{~kg} /$ person/year (Figure 17). It would thus increase by $4.4 \%$ from the 2020 forecast $(28.87 \mathrm{~kg} /$ person/year).

\section{Discussion}

\subsection{Possible Trends in Meat Consumption and Their Impact on the Sustainability of Its Production}

In terms of the sustainability of livestock production in the Czech Republic, it is necessary to pay attention to current trends in the development of meat consumption, i.e., new directions in nutrition and other facts that affect meat consumption. The amount of meat consumption is not only affected by its price, but also by the increasing attention paid to a healthy lifestyle and environmental protection.

\subsubsection{Healthy and Rational Nutrition}

As stated by Pánek [41], at present, the trends of a healthy lifestyle are becoming more and more popular and there can be no doubt that healthy nutrition is part of a healthy lifestyle. By healthy nutrition, we mean a supply of sufficiently high-quality food, without chemicals, with sufficient nutritional value to ensure healthy growth and enough energy for all activities. However, the body must not have an excess of this energy [41].

Man obtains energy from food, specifically from its three components, which are: proteins, fats and sugars. These individual components of the nutrition must be in a certain combination and in a certain amount, the following ratio being recommended: $15 \%$ proteins, $30 \%$ fats and $55 \%$ sugars. According to current scientific knowledge, this ratio of individual components will ensure the proper and healthy functioning of the organism [42].

Vitamins and minerals are other essential components of food from the point of view of healthy nutrition $[43,44]$. Within healthy nutrition, a balanced supply of individual vitamins and minerals to the human body is essential. It follows from the above that meat also has its irreplaceable place in human nutrition; it is only about quantity and also form. For example, sausages are not part of healthy nutrition. However, chicken, rabbit, but limited pork and beef, are the basis of varied nutrition.

More and more people today pay attention to the principles of a healthy lifestyle. These include rational nutrition. Diet and its composition significantly affect the health of each individual. The diet must be balanced and must not be depleted of important components, or, conversely, there must be no excess of these components. According to Petrásek [45], the human body needs 45 nutrients for its smooth functioning, and each of these nutrients has its irreplaceable place in human nutrition.

Štiková et al. [46] point out that meat consumption can be included among the risky behaviors that subsequently lead to obesity. Excessive consumption of meat leads to a number of diseases, such as heart disease, poor blood pressure, diabetes, liver and spleen disorders and especially cancer. More and more people are trying to eat rationally, but there is also a large number of people who do not know the rational way of eating. Due to the growing wealth of the population, these people buy more and more food, including meat [46].

\subsubsection{Vegetarianism and Veganism}

Other ways of nutrition that significantly affect the consumption of meat and thus the sustainability of its production are vegetarianism and veganism. Vegetarianism is a way of eating where meat is excluded from the diet. Veganism is a diet that completely excludes all animal products. There are many reasons why people lean towards one or the other. It is most often for ethical reasons that people refuse to kill and use animals for the purpose of consuming or making clothes [45]. These choices are driven by attention 
to sustainability (environmental impact), also highlighting some inconsistencies between attention to sustainability and these lifestyles (vegetarianism and veganism).

According to research carried out by the STEN/MARK agency, there are an estimated 200,000 people in the Czech Republic who profess vegetarianism. In addition, the number of vegetarians is still growing, especially among young people. The number of vegans is unknown [45].

However, there are also many people who choose vegetarianism or even veganism because of the belief that these dietary methods have a positive impact on human health. However, it cannot be said unequivocally that eating only a plant-based diet is healthier; it always depends on the composition of the diet [45]. According to Dostalová and Kadlec [29], however, vegetarian and therefore vegan diets are characterized mainly by a lack of iodine, calcium, vitamin B12 and iron.

Cofnas et al. [47] state that a large study carried out among vegetarians and nonvegetarians did not show that vegetarians were healthier. On the contrary, they state that in some cases, vegetarianism may be a worse choice for health than rational eating, including meat consumption.

\subsubsection{Food Supplements}

Today, quality and varied food is often replaced by food supplements in the Czech Republic. The first of these appeared on the market around the middle of the 20th century. At present, however, the offer of food supplements, and especially the types of substances and vitamins contained in them, is many times greater [48].

Food supplements are concentrated sources of bioactive compounds (i.e., minerals, amino acids, vitamins, herbs or other botanicals, and other dietary ingredients) to supplement the normal diet by increasing the total intake of these substances, but they are not intended to treat disease [49]. The demand for functional foods and dietary food supplements in the global market have increased rapidly, according also to the popular belief, although sometimes wrong, that 'natural' is healthier and safer than synthetic drugs [50].

Among people who are interested in a healthy lifestyle and sports, there are many more who limit the intake of certain types of food, such as sugar, flour, but also meat. As Clark [51] points out, the missing nutrients are then obtained from supplements; however, this is not natural. Thus, a certain decrease in meat consumption can be attributed to the fact that people replace the necessary nutrients with food supplements.

\subsubsection{Ethical Reasons for Reducing Meat Consumption}

Czech consumers' decision-making based on ethical criteria is becoming more frequent today. More and more people in the Czech Republic are making decisions based on what impact their decisions have on the environment or whether someone else's rights are being infringed.

The fact is that agriculture, but especially meat production, has very significant effects on the environment. It is necessary to recall that livestock production uses as much as $30 \%$ of the land not covered with ice. Livestock production is responsible for the destruction of forests that are burned to obtain pastures, for soil degradation and, last but not least, livestock is one of the largest producers of greenhouse gases, thus contributing to global warming [52]. Steinfeld [52] further states that livestock production also has a very high level of water consumption. According to the Food and Agriculture Organization (FAO) [12], the production of $1 \mathrm{~kg}$ of beef consumes 15,000 L of water, approximately $6000 \mathrm{~L}$ of water are used to produce $1 \mathrm{~kg}$ of pork and $4300 \mathrm{~L}$ of water are used to produce $1 \mathrm{~kg}$ of chicken. On average, livestock production consumes $0.6 \%$ of drinking water. In some parts of the world, it is up to $23 \%$, for example in Botswana. As a result of these findings, more and more people are resorting to significantly reducing meat consumption or omitting it altogether from their diet [52].

In addition to the environmental impacts already mentioned, many people are also reducing meat consumption for animal rights reasons. This increases the popularity of 
organic and other products that ensure the respectful treatment of animals. Consumers would rather pay extra and reduce their meat consumption than support businesses that commit animal cruelty or where animals have to live in unsatisfactory conditions [52].

If we summarize the findings obtained from the study of current trends in meat consumption, we find that meat consumption is beginning to be considered unethical, especially from the point of view of environmental protection and animal protection. This also increases the number of people who reduce meat consumption. However, other factors also affect the size of meat consumption, for example, its price. There is also no change for all types of meat.

\subsection{Evaluating the Validity of the Hypothesis and Results of the Analysis}

Based on an analysis of the available data from the Czech Statistical Office [27], scientific studies, reports about the state of livestock production in the Czech Republic, as well as the knowledge gained on the relations between suppliers and consumers of pork meat commodities, it can be concluded that the established hypothesis has been confirmed and that sustainable meat consumption depends primarily on the consumer habits of the population and significant fluctuations in the market prices of meat.

The mutual relationship between the production of pork, beef and poultry meat in the Czech Republic results from the residual data of the time series of production from the years 2000-2019 and from the adjusted values calculated by the method of exponential smoothing. The results of the calculations show an intense positive relationship between pork and beef production in the Czech Republic and confirm a certain stability of the structure and character of livestock production in Czech agriculture. Poultry meat production is also significant, as it accounts for $36.7 \%$ of the total meat production in the Czech Republic (see Table 1).

Knowledge about the relationship between production and consumption of meat and its individual types in the Czech Republic can be summarized in the following findings. As statistical analysis of the data showed:

- Meat production in the Czech Republic increased slightly by $0.4 \%$ year-on-year $2019 / 2018$ to 450.8 thousand tons. The total consumption of meat in the Czech Republic shows stable values, which according to the prediction should continue (until 2024 it would change only by $+0.1 \mathrm{~kg} /$ person/year). There is therefore no contradiction between future production and consumption.

- $\quad$ Pork meat production in the Czech Republic has seen a significant declining trend since 2004 and reached its minimum in 2019. On the contrary, pork consumption shows a growing trend in the future. By 2024, pork consumption should increase by $0.61 \mathrm{~kg} /$ person/year, i.e., by $1.4 \%$. This enables the sustainable development of pork meat production in the Czech Republic and, given the low self-sufficiency in its production (approximately 51\%), it gives Czech farmers the prospect of secure sales.

- Beef and veal production in 2019 increased by $1.8 \%$ year-on-year. The lowest production was in 2014. However, the consumption of this type of meat in the Czech Republic has also increased slightly since 2013, and according to the prediction calculated by Holt's model, it should be stable by 2024 and be around $8.66 \mathrm{~kg} /$ person/year. However, beef is too expensive for today's households in the Czech Republic and difficult to cook. This limits the sustainable development of its production, which is further complicated by insufficient use of processing capacities (due to labor shortages), insufficient demand (self-sufficiency of around 140\%) and achieving better prices for producers by exporting live cattle to foreign markets. Moreover, beef is considered a very pollutant food, mainly regarding greenhouse gas (GHG) or global warming potential (GWP) [12].

- In 2019, the Czech Republic produced more poultry meat by $1.02 \%$ year-on-year. Production has been increasing every year since 2013, but poultry farming is a marginal issue for Czech primary producers. Consumption of poultry meat in the Czech Republic has been increasing since 2013 and, according to the forecast, should continue 
to grow. In 2024, it could increase by $4.4 \%$ compared to 2020 . The main exporter of poultry meat to the Czech Republic is Poland. Poultry meat is considered healthy by consumers. However, the sustainable development of poultry meat production and consumption is significantly influenced by the EU directive on the abolition of cage farming, which in turn will allow for better animal welfare, but may generally lead to more expensive production of poultry meat and eggs. On the other hand, for many people, this can lead to greater confidence in the quality of poultry meat, including support for the ethical aspects of the matter.

With regard to current trends in the sustainable development of livestock production, it is not possible to answer unequivocally the question of whether meat consumption is influenced only by the interest in healthy nutrition. Both the price and the interest in healthy nutrition are probably contributing to the new trends in meat consumption. However, for a certain group of people, price will certainly be the most important factor. However, it can be assumed that with the rising standard of living of the population, the interest in a healthy lifestyle and thus healthy nutrition will also grow.

\subsection{Recommendations for Government and Practice}

- The first step that should be taken to improve the situation in Czech agriculture in the production of pig meat is to restrict imports of animal products at dumping prices from Poland and Germany, for example.

- Expansion of the currently insufficient processing capacities. For many years, the Czech Republic has thus been exporting unprocessed commodities such as milk and cattle and importing final products such as pig meat and cheeses.

- The unification of support for farmers in the European Union to ensure a level playing field for their businesses would have significant impact as well.

- Support for farmers that are associated through the formation of sales cooperatives should be increased as well. They could have both tax reliefs and, for example, be given precedence in grant programs; another option would be to waive their social and health insurance payment obligations.

- The state should also improve the conditions for receiving foreign workers, who could be employed seasonally in both livestock and crop production in agriculture.

\section{Conclusions}

Historically, Czech agriculture was evenly focused on crop and livestock production due to its soil and climatic conditions. With the accession of the Czech Republic to the EU, the structure of Czech agriculture changed to the detriment of livestock production. The decisive sectors of livestock production are pig breeding, cattle breeding and poultry farming. In the Czech Republic, beef remains the only type of meat for which production exceeds consumption. The Czech Republic exports live cattle, but it has to import beef.

However, Czech agriculture is currently heavily subsidized. "If we consider the EUR 920 million of annual profit and compare it with the EUR 1.53 billion in annual support from EU subsidies and the state budget (including tax reliefs on green diesel), Czech agriculture would be an unprofitable sector without subsidies. The vast majority of profits are also invested back into the sector. The landscape and field production in the Czech Republic look good, but livestock production and the food sector have long been underfunded and lack investments" [31].

However, agriculture is a promising sector for the Czech economy. Even from a simplistic point of view, the number of people on the planet will continue to grow [53]; the demographic curve is a given. There are regions that are highly-populated and will be unable to feed themselves. They will have to buy food (an example is the current export of Czech meat to China, Nigeria and Angola), which is a great opportunity for the EU and Czech agriculture [54]. Livestock products are important for global food security because they provide $17 \%$ of global calorie consumption and $33 \%$ of global protein consumption [55-58]. 
There are two trends in meat consumption that are geographically determined. While in developed countries, meat consumption is declining, in developing countries, meat consumption is rising. Thus, due to the development of meat consumption, the Czech Republic is one of the developed economies where meat consumption is declining or stagnating for various reasons. Most often it is the protection of animals, health reasons or the protection of the planet.

The meat consumption in the Czech Republic in 2016 was $80.3 \mathrm{~kg}$ per person. Compared to 1936, when this meat consumption amounted to $38.1 \mathrm{~kg}$ per person, it represents an increase of roughly $111 \%$ [27].

Furthermore, a statistical forecast of meat consumption in the Czech Republic was created; it expresses the current and expected development of meat consumption for key types until 2024. The total consumption of meat in the Czech Republic shows a stable value, which should persist:

- $\quad$ Pork consumption shows a growing trend in the future. However, this aspect runs into nutritional recommendations and is related to the high incidence of obesity and diabetes in the Czech population. The Czech Republic's nutrition policy still draws attention to the need to limit the consumption of traditional pork and the possibility of replacing it with fish and game.

- Beef is too expensive for today's households and difficult to cook. Its future consumption calculated by Holt's model is constant and should be around $8.66 \mathrm{~kg} /$ person/year.

- Poultry meat is considered healthy by consumers. Its consumption should continue to increase, and the model shows that in 2024 it could reach the level of 30.13 $\mathrm{kg} /$ person/year.

In the developed world, we have also recently seen a number of activities and movements that highlight the benefits of a healthy lifestyle and healthy nutrition, which of course includes prudent meat consumption. More and more consumers also prefer the quality of meat, for example, by buying meat from small producers, buying meat in organic quality, even at a higher price.

The analysis also shows that in the case of pork, price is not a decisive factor in forcing consumers to change their habits. For beef, the opposite is true. In the case of pork, which is consumed many times more every year, the reasons for the change are different. In particular, there is a growing interest in a healthy lifestyle, which includes a healthy and balanced diet.

Summarizing the above findings, socio-economic aspect of the sustainable development of livestock production in the Czech Republic is given mainly by the relationship between meat production and consumption, while the main influences on meat consumption are new trends in consumption and fluctuations in the market prices of this commodity. The sustainable development of livestock production in Czechia is further influenced by significant environmental factors, such as high water consumption in meat production, greenhouse gas emissions and global warming potential.

Author Contributions: Conceptualization, K.Š.; methodology, M.P. and M.Š.; software, R.S.; validation, L.S. and M.Š.; formal analysis, K.Š.; investigation, K.Š.; resources, M.P.; data curation, L.S.; writing—original draft preparation, K.Š. and R.S.; writing—review and editing, M.P. and L.S.; visualization, M.P.; supervision, L.S.; project administration, K.Š.; funding acquisition, K.Š. All authors have read and agreed to the published version of the manuscript.

Funding: This research was funded by the Faculty of Economics and Management, Czech University of Life Sciences in Prague, grant number 20181015.

Institutional Review Board Statement: Not applicable.

Informed Consent Statement: Not applicable.

Data Availability Statement: Data sharing not applicable.

Conflicts of Interest: The authors declare no conflict of interest. 


\section{References}

1. Marunelu, I. Research on the Small Peasant Individual Households in Romania within the Framework of Sustainable Agriculture. Sci. Pap. Ser. Manag. Econ. Eng. Agric. Rural Dev. 2020, 20, 341-346.

2. Lv, Y.; Zhang, C.; Ma, J.; Yun, W.J.; Gao, L.L.; Li, P.S. Sustainability Assessment of Smallholder Farmland Systems: Healthy Farmland System Assessment Framework. Sustainability 2019, 11, 4525. [CrossRef]

3. Brohm, K.A.; Klein, S. The Concept of Climate Smart Agriculture-A Classification in Sustainable Theories. Int. J. Qual. Res. 2020, 14, 291-302. [CrossRef]

4. European Commission. EU Approach to Sustainable Development. Available online: https://ec.europa.eu/info/strategy/ international-strategies/sustainable-development-goals/eu-approach-sustainable-development_en (accessed on 16 December 2020).

5. Prus, P. Sustainable Farming Production and Its Impact on the Natural Environment-Case Study Based on a Selected Group of Farmers. In 8th International Scientific Conference on Rural Development-Bioeconomy Challenges. Proceedings of the 8th International Scientific Conference on Rural Development-Bioeconomy Challenges, Akademija, Lithuania, 23-24 November 2017; Raupeliene, A., Ed.; Aleksandras Stulginskis University: Akademija, Lithuania, 2017; pp. 1280-1285.

6. Kowalska, M.; Knapik, W.; Bogusz, M. Zrównoważony rozwój obszarów wiejskich. Probl. Ekorozw. 2016, 11, 81-88.

7. Silva, C.L.M.; Costa, R.; Pittia, P. Responsible research and innovation in the food value chain. J. Food Eng. 2017, 213, 1. [CrossRef]

8. Wesana, J.; de Steur, H.; Dora, M.K.; Mutenyo, E.; Muyama, L.; Gellynck, X. Towards nutrition sensitive agriculture. Actor readiness to reduce food and nutrient losses or wastes along the dairy value chain in Uganda. J. Clean. Prod. 2018, 182, 46-56. [CrossRef]

9. Mathias, J.F.C.M. Manure as a Resource: Livestock Waste Management from Anaerobic Digestion, Opportunities and Challenges for Brazil. Int. Food Agribus. Manag. Rev. 2014, 17, 87-109.

10. Kašparová, K.; Svoboda, R.; Severová, L.; Hinke, J. Evaluation of the performance of Czech agriculture. Indian J. Agric. Res. 2019, 53, 522-528.

11. Ranucci, D.; Miraglia, D.; Branciari, R.; Morganti, G.; Roila, R.; Zhou, K.; Jiang, H.Y.; Braconi, P. Frankfurters made with pork meat, emmer wheat (Triticum dicoccum Schubler) and almonds nut (Prunus dulcis Mill.): Evaluation during storage of a novel food from an ancient recipe. Meat Sci. 2018, 145, 440-446. [CrossRef]

12. Food and Agriculture Organization (FAO). Agricultural Statistics. Available online: http://www.fao.org/home/en/ (accessed on 23 November 2020).

13. Henchion, M.; Hayes, M.; Mullen, A.M.; Fenelon, M.; Tiwari, B. Future protein supply and demand: Strategies and factors influencing a sustainable equilibrium. Foods 2017, 6, 53. [CrossRef]

14. Alvarez, C.; Drummond, L.; Mullen, A.M. Protein recovered from meat co-products and processing streams as pork meat replacers in Irish breakfast sausages formulations. LWT Food Sci. Technol. 2018, 96, 679-685. [CrossRef]

15. Nunez, Y.; Fermoso, J.; Garcia, N.; Irusta, R. Comparative life cycle assessment of beef, pork and ostrich meat: A critical point of view. Int. J. Agric. Resour. Gov. Ecol. 2005, 4, 140-151. [CrossRef]

16. Jiménez-Colmenero, F.; Sánchez-Muniz, F.J.; Olmedilla-Alonso, B. Design and development of meat-based functional foods with walnut: Technological, nutritional and health impact. Food Chem. 2010, 123, 959-967. [CrossRef]

17. Weiss, J.; Gibis, M.; Schuh, V.; Salminen, H. Advances in ingredient and processing systems for meat and meat products. Meat Sci. 2010, 86, 196-213. [CrossRef]

18. Hung, Y.; de Kok, T.M.; Verbeke, W. Consumer attitude and purchase intention towards processed meat products with natural compounds and a reduced level of nitrite. Meat Sci. 2016, 121, 119-126. [CrossRef]

19. Shan, L.C.; Regan, Á.; Monahan, F.J.; Li, C.; Lalor, F.; Murrin, C.; McConnon, Á. Consumer preferences towards healthier reformulation of a range of processed meat products: A qualitative exploratory study. Br. Food J. 2017, 119, 2013-2026. [CrossRef]

20. Cebulska, A.; Vaclavkova, E.; Bocian, M.; Dybala, J.; Wisniewska, J.; Kapelanski, W. Quality and Dietary Value of Pork Meat of the Pulawska and Zlotnicka Spotted Breeds, and Commercial Fattening Pigs. Ann. Anim. Sci. 2018, 18, 281-291. [CrossRef]

21. Mendoza, E.; García, M.L.; Casas, C.; Selgas, M.D. Inulin as fat substitute in low fat, dry fermented sausages. Meat Sci. 2001, 57, 387-393. [CrossRef]

22. Nevrkla, P.; Kapelanski, W.; Vaclavkova, E.; Hadas, Z.; Cebulska, A.; Horky, P. Meat Quality and Fatty Acid Profile of Pork and Backfat from an Indigenous Breed and a Commercial Hybrid of Pigs. Ann. Anim. Sci. 2017, 17, 1215-1227. [CrossRef]

23. European Commission. European Commission Regulation (EU) No 10/2011 of 14 January 2011 on Plastic Materials and Articles Intended to Come into Contact with Food. Available online: https://eur-lex.europa.eu/legal-content/EN/ALL/?uri=CELEX\% 3A32011R0010 (accessed on 15 May 2020).

24. Zmit, B.; Kerboua, K.; Bali, A.; Souahi, F.; Belhaneche-Bensemra, N. Combining numerical and fundamental approaches for the overall PET migration prediction: Case of mineral water bottles. Eur. Food Res. Technol. 2017, 243, 123-131. [CrossRef]

25. Bonneau, M.; Antoine-Ilari, E.; Phatsara, C.; Brinkmann, D. Diversity of pig production systems at farm level in Europe. J. Chain Netw. Sci. 2011, 11, 115-135. [CrossRef]

26. Hindls, R.; Hronová, S.; Novák, I. Metody Statistické Analýzy pro Economy; Management Press: Praha, Czech Republic, 2000.

27. Czech Statistical Office (CZSO). Agriculture. Available online: https:/ / www.czso.cz/csu/czso/agriculture_ekon (accessed on 29 September 2020).

28. Pánková, B. Sucho srazilo zisky zemědělců o pětinu. E15 2019, 8, 4. 
29. Dostálová, J.; Kadlec, P. Potravinářské Zbožiznalství: Technologie Potravin; Key Publishing: Ostrava, Czech Republic, 2014.

30. Czech News Agency (CNA). Hovězího a vepřového masa se vyrobilo méně. Mf Dnes 2019, 31, 9.

31. Ministry of Agriculture of the Czech Republic. News. Available online: http://eagri.cz/public/web/en/mze/ (accessed on 5 October 2020).

32. Agricultural Association of the Czech Republic. Aktuality. Available online: https:/ /www.zscr.cz/Aktuality (accessed on 16 October 2020).

33. Czech Confederation of Commerce and Tourism. News. Available online: https://www.spcr.cz/en/news (accessed on 13 January 2021).

34. Czech Meat Processors Association. Aktuality. Available online: http://www.cszm.cz/aktuality.asp (accessed on 27 November 2020).

35. Pánková, B. Česko exportuje skot, ale hovězí musí dovážet. E15 2019, 27, 4.

36. Czech News Agency. Zájem Čechů o Slevy Roste, v Akci Kupují Polovinu Zboží. Available online: https:/ /zpravy.aktualne.cz/ ekonomika/ceska-ekonomika/zajem-cechu-o-slevy-roste-v-akci-kupuji-polovinu-zbozi/r \{\}i:article:774619/ (accessed on 11 January 2021).

37. Pavlů, M. Faktory Ovlivňující Spotřebu Vepřového. Available online: https:/ / www.zemedelec.cz/faktory-ovlivnujici-spotrebuveproveho/ (accessed on 17 October 2020).

38. Kameník, J. Maso Jako Potravina: Produkce, Složení a Vlastnosti Masa; Veterinární a farmaceutická univerzita: Brno, Czech Republic, 2014.

39. Oliinyk, A. Nové Trendy ve Spotřebě Potravin; PEF ČZU v Praze: Prague, Czech Republic, 2020.

40. Štiková, O.; Sekavová, H.; Mrhálková, I. Vliv Změny Cen na Spotřebu Potravin; Výzkumný Ústav Zemědělské Ekonomiky: Prague, Czech Republic, 2006.

41. Pánek, J. Základy Výživy; Svoboda Servis: Praha, Czech Republic, 2002.

42. Fořt, P. Tak co Mám Jíst; Grada: Prague, Czech Republic, 2007.

43. Mindell, E. Vitaminová Bible pro 21. Století: Vše o Vitaminech, Které Budete v Tomto Století Potřebovat; Knižní klub: Prague, Czech Republic, 2000.

44. Kubešová, H. Výživa Jako Nástroj pro Podporu Zdravi a Udržení Kondice ve Vyšším Věku: Zdravá Výživa v Otázkách a Odpovědích; Protis: Podolí u Brna, Czech Republic, 2008.

45. Petrásek, R. Co Dělat, Abychom Žili Zdravě; Vyšehrad: Prague Czech Republic, 2004.

46. Štiková, O.; Sekavová, H.; Mrhálková, I. Vývoj Spotřeby Potravin a Analýza Základních Faktorů, Které ji Ovlivňují; Výzkumný ústav zemědělské ekonomiky: Prague, Czech Republic, 2004.

47. Cofnas, N. Is Vegetarianism Healthy for Children? Critical Reviews in Food Science and Nutrition. Available online: https: / / www.tandfonline.com/doi/full/10.1080/10408398.2018.1437024 (accessed on 18 November 2020).

48. Hanzlová, J.; Hanzlová, A. Používání Potravinových Doplňků v Různých Věkových Skupinách. Available online: http:/ /www. ped.muni.cz/z21/2006/konference_2006/sbornik_2006/pdf/083.pdf (accessed on 19 November 2020).

49. Fibigr, J.; Šatínský, D.; Solich, P. Current trends in the analysis and quality control of food supplements basedon plant extracts. Anal. Chim. Acta 2018, 1036, 1-15. [CrossRef]

50. Boggia, R.; Zunin, P.; Turrini, F. Functional Foods and Food Supplements. Appl. Sci. 2020, 10, 8538. [CrossRef]

51. Clark, N. Sportovní Výživa: Pro Pěknou Postavu, Dobrou Kondici, Výkonostní Trénink; Grada: Prague, Czech Republic, 2000.

52. Steinfeld, H. Livestock's Long Shadow. Environmental Issues and Options; Food and Agriculture Organization of the United Nations: Roma, Italy, 2006.

53. United Nations. Population. Available online: https://www.un.org/en/sections/issues-depth/population/ (accessed on 11 January 2021).

54. Kütner, D. Hamé získalo nové trhy ve střední Africe a Vietnamu. E15 2015, 27, 4.

55. Rosegrant, M.W.; Fernandez, M.; Sinha, A. Looking into the future for agriculture and AKST. In International Assessment of Agricultural Knowledge, Science and Technology for Development (IAASTD), Agriculture at a Crossroads; McIntyre, B.D., Herren, H.R., Wakhungu, J., Watson, R.T., Eds.; Island Press: Washington, DC, USA, 2009; pp. 307-376.

56. Kosiciarova, I.; Kadekova, Z.; Dzupina, M.; Kubicova, L.; Dvorak, M. Comparative Analysis of Private Labels-Private Labels from the Point of View of a Millennial Customer in Slovakia, Czech Republic and Hungary. Sustainability 2020, 12, 9822. [CrossRef]

57. Malý, M.; Hálová, P.; Havlíková, M.; Žáková-Kroupová, Z. Valuation of public goods: The case of emissions from livestock holdings in the Czech Republic. Agris Line Pap. Econ. Inform. 2017, 9, 99-111. [CrossRef]

58. Rahman, S. Agroecological, Land-Elevation and Socioeconomic Determinants of Raising Livestock in Bangladesh. Agriculture 2018, 8, 12. [CrossRef] 